\title{
Study of the Migratory Return: Analysis to the Condition of the Returned Migrant in the Educational and Labor Reintegration and the Entrepreneurship as an Area of Opportunity
}

\author{
Iris E. Betanzos \\ $\mathrm{PhD}$ student at Strategic Planning and Management in Technologies, \\ Popular Autonomous University of the State of Puebla, México
}

Doi: 10.19044/esj.2018.v14n10p83 URL:http://dx.doi.org/10.19044/esj.2018.v14n10p83

\begin{abstract}
Studies on the educational and labor reintegration of migrants returned to Latin American countries have gained importance due to the economic and social implications of rehabilitation. In this article, the return of the migrant was considered part of the migration process. An exploratory research of publications in different international journals was carried out; when consulting the referenced articles, it was identified that at the time of return the migrant presents and perceives a moral, social, educational and work imbalance. From the deficiencies found in the theoretical lines studied Educational reinsertion, Labor reintegration - the third theoretical line was included the importance of relating the concept of entrepreneurship as an area of opportunity for returned migrants. The results of the analysis of the studies and theoretical frameworks of international migration, showed great similarities of the phenomenon in different geographical spaces, being an indispensable tool to understand their different forms, evolution and development both in the countries of origin and destination.
\end{abstract}

Keywords: Returned migrants, Educational insertion, Labor insertion, Entrepreneurship

\section{Introduction}

International migration, whether forced or voluntary, is a historical phenomenon that entails multiple reasons of an economic, political, social and cultural nature. Border population movements are common and, in times of peace and outside of climatic catastrophes, they have to do with the demand and supply of productive factors, border control strategies and the modalities of economic integration between the countries involved (Castles, cited in 
Delgado and Mañan, 2005). The migratory phenomenon has been of great importance due to its magnitude and permanence (Contreras, 2016).

During the last 15 years, international population movements have undergone significant changes in volume, trends, modalities and sociodemographic characteristics. Return migration is not a new phenomenon, it has traits that distinguish it from the migratory flows of the past; the economic crisis and the implementation of restrictive migration policies are some of the factors that have encouraged return flows in recent years (Ramírez and Aguado, 2013).

This is a moment of great changes in migration policy, not only in the normative terrain (new unilateral rules), but also in the creation of a new bureaucratic-administrative apparatus that has modified the migratory dynamics (Gandini, Lozano and Gaspar, 2015).

From the above, it constitutes a return that incorporates a high dose of vulnerability: these are migrants who have remained for long periods abroad; this vulnerability expresses to a large extent the fear of being deported due to an accumulation of economic, social and political factors (Mestries, 2013).

In this sense, the concern that within the report on Human Development, sustains human progress, by reducing vulnerabilities and building resilience (UNDP, 2014); is that although most countries have made consistent progress in this area, there is still a precarious feeling to the extent that achievements in fundamental aspects of development can be broken very quickly in the face of certain events, such as economic crises and natural disasters (Idem). This situation of vulnerability is the one that faces, to a great extent, the population of the returned migrants in their processes of educational and labor reintegration.

The return must be thought of as a constituent element of the migrant condition, a complex element that contains in itself the process, the desire and the life project of those who undertake the return home: one more element of the migratory cycle (Fabre, 2016).

In this way, the study of the migratory return currently acquires a different aspect and can be recognized as the main manifestation and effect of this new migratory phase (Durand, 2013, Canales, 2012). Until now, specialists have ruled out analyzing with the required force, the causes of and effects on those who return. It is necessary to investigate about the historical, sociological, psychological, economic, and political dimension that this movement brings with it (Fabre, 2016).

The objective of the research is to analyze, from the perspective of the different theorists, the condition of the returned migrant in the educational and labor reintegration and the link that exists between them and entrepreneurship. 


\section{Educational reinsertion}

Beyond the national and international regulations that guarantee the rights of migrants, it is possible to identify the existence of different types of educational barriers that impede the enjoyment of immigrants' right to education.

The education is one of the main pillars in the economic development of a country, and a relevant factor in the growth projects as migratory support; which can provide security and positive experiences of inclusion of migrants returned to society (Sánchez, 2014). Therefore, if these migrants decide to relocate, they must integrate into this new society where they will find educational and work conditions different from those acquired in their previous place of residence; that's why, it will be necessary to weave new networks and, possibly, face situations of rejection or discrimination (Cobo, 2008).

In the international context, there is overcrowding in institutions, which leads to the return of migrants to the degrees according to the availability of seats. Despite the classification exams, in cases where they do not have their academic record, these immigrants are sometimes assigned to lower levels that do not correspond to their age or knowledge, which influences their self-esteem and motivation. To continue studying since they do not find challenges to overcome (Sánchez, 2014).

International return migration is negatively linked to the educational trajectory of children who participate in this type of mobility. An investigation carried out showed that recent immigrant children in the United States have greater non-attendance and lag than their non-immigrant counterparts, even after taking into account the cultural and social human capital of their families and the context of the place of reception (Vargas, 2015).

Studies conducted regarding Latin American migrants-especially the Peruvian community- indicates that they are visualized based on stereotypes associated with race, poverty, and delinquency, among others - that operate as a source of discrimination (Tijoux, 2013). In this way, being a migrant's child is considered different from the local, which leads to stigmas when being identified as an other/ migrant different from us / national / even in the case of children who have never migrated spatially or who are not foreigners in legal terms (Salas, Kong, Gazmuri, 2017).

About it, the Mexican environment, Pederzini, Riosmena, Masferrer and Molina (cited by Jensen, 2017) explain that return flows have provoked new questions and considerations about opportunities and integration for migrants; concerns about integration have been reversed; the new questions address how Mexican institutions should incorporate migrants.

When evaluating the differences in the risks of absenteeism and school lag, it was found that immigrants born in Mexico had greater disadvantages 
than those born in the United States, compared to non-immigrants. This is consistent with previous research that found that birth in the United States is a protective factor for the schooling of adolescents (Giorguli and Gutiérrez, 2011).

Based on the educational welfare approach of the returnees Zúñiga, Hamann (et al., 2013) found results on the school trajectories of these children, integration processes or school exclusion and the formation of transnational identities. His team has carried out about 54,000 surveys in primary and secondary schools in the states of Nuevo León (2004), Zacatecas (2005), Puebla (2009) and Jalisco (2010). They conducted follow-up interviews with selected students and teachers. They found that between two and three percent of the students surveyed were transnational, that is, they had lived at some time in the US; most of them -about two thirds- were born in Mexico (Zúñiga and Hamann, 2009), although these returned migrants continued to identify with their American affiliation (Hamann and Zúñiga, 2011). Returned students said they felt out of place in Mexican schools (Zúñiga, Hamman and Sánchez, 2008), and had to struggle with the formation of their identity in a new environment (Zúñiga and Hamann, 2009). They reported difficulties in speaking Spanish and uncertainty about their future in relation to work and place of residence (Hamann, Zúñiga and Sánchez, 2010).

In Mexico, research highlights psychosocial factors that are experienced in migration and return as well as the school processes of the children of those who leave the country; they propose to problematize the lack of research and documentation on the return of Mexican migrants in a country that, historically, has had high numbers of population mobility (Ocampo, 2014).

The Mexican school system is designed for students who do not migrate to the United States, who have not been born in that country, who do not have their parents living and working there. These binational children and adolescents, these transnational students, these children separated from their parents by migration do not exist in the teacher training programs, nor in the plans to update the teaching profession, nor in the curricular designs, nor in the content, nor in the narratives, neither in the evaluations, nor in the policy discourse (Zuñiga, 2013).

About it, in the Chilean context during the last 10 years a group of studies has focused on the influences that occur between students, teachers and other members of the educational community regarding migration. For example, the studies by Tijoux (2013) have emphasized the need to have antiracist education, given the situations of discrimination faced by migrants in school contexts in Chile (Joiko and Vázquez, 2016).

The studies carried out in Chile, regarding migration and school, present two approaches: 1) Public policies regarding the migrant phenomenon, 
from the perspective of human rights; resulting in difficulties for the integration of returned students, mainly due to lack of resources, training in education and the absence of guidelines; consequence of a deficit migration law (Berrios and Palou, 2014). 2) The perspective of migrant schoolchildren, their teachers and their families from the concepts of identity and discrimination, especially in childhood. The results of these investigations show processes of change that schools make to create inclusive practices adapting their own integration projects (Salas, Kong, Gazmuri, 2017).

Despite the aforementioned studies, up to now there is not enough evidence on the characteristics, profiles and form in which migrant children and adolescents live their school processes; it turns out to be a complex issue to address, both in terms of reintegration and inclusion.

\section{Labor Reintegration}

There are several international studies (Table 1) that contribute to the knowledge of the labor reinsertion of returnees quantitative approaches, based on the use of censuses or household surveys. The development of efficient institutional mechanisms of labor reintegration begins with knowing the labor profile of these migrants (Peña, 2015).

Returnees face additional challenges; they face contexts other than those of their departure, with limited information on the jobs available, with difficulties in checking their work experience abroad and revalidating studies and certifications. At the same time, the social networks of the returnees can not necessarily facilitate their reintegration if the stay abroad was long and run the risk of being stigmatized by the conception of crime associated with deportation (Masferrer, Sánchez, Rodríguez, 2017).

Table 1 Contributions of authors who have studied related to the returned migrant and labor reintegration

\begin{tabular}{|c|c|c|}
\hline Author & Variables and / or contributions \\
\hline Koolhaas, 2016 & $\begin{array}{c}\text { The differences in the unemployment tendency of the returnees are } \\
\text { located according to the residence time in Uruguay. Finding that, } \\
\text { the shorter the time of residence in the country, the greater the } \\
\text { propensity to be unemployed. The highest level of education } \\
\text { attained is another attribute that affects the access to employment } \\
\text { of Uruguayan returnees with respect to non-migrants. According to } \\
\text { the results of the logistic models, the disadvantaged situation of the } \\
\text { returnees compared to the people without migratory experience } \\
\text { seems to be accentuated as the educational level of the individuals } \\
\text { increases. }\end{array}$ \\
\hline $\begin{array}{c}\text { Montoya y } \\
\text { González, 2015 } \\
\text { that will be plated to the returnees for their reinsertion and in } \\
\text { which way they will take advantage of the labor skills that they } \\
\text { acquired during their stay in the United States or the social benefits } \\
\text { that the migratory experience can bring. }\end{array}$ \\
\hline
\end{tabular}




\begin{tabular}{|c|c|}
\hline Rivera, 2015 & $\begin{array}{c}\text { He studied the effects on the probability of getting a job in the } \\
\text { labor market; it was explored if the accumulated human capital has } \\
\text { a relevant role in the process of labor reintegration and perception } \\
\text { of the returnee and those who receive it. This research offered } \\
\text { evidence that the experience of living in a place different from the } \\
\text { place of origin, and contact with other people with different } \\
\text { cultural contexts, are factors that contribute to the positioning of } \\
\text { returnees in the labor market. }\end{array}$ \\
\hline Rivera, 2013 & $\begin{array}{c}\text { In the Mexican environment, the accumulated human capital is } \\
\text { tested by observing the role it plays in the process of labor } \\
\text { reintegration. }\end{array}$ \\
\hline Anguiano, Cruz y & $\begin{array}{c}\text { The successful labor reinsertion of returning migrants from the } \\
\text { United States was emphasized in that it will depend on the human } \\
\text { capital and the monetary resources acquired, as well as on the } \\
\text { employment and investment opportunities existing in the } \\
\text { communities of origin in Mexico and on the imagination and } \\
\text { inventiveness of migrants. }\end{array}$ \\
\hline
\end{tabular}

Source: own elaboration, various sources; 2017

\section{Entrepreneurship of Migrants}

With the above, it is attributed that returned migrants find it difficult to find stable and remunerative jobs, because half of those who manage to get work on their return $-70 \%$ of the total- do so in the informal sector and earn up to a minimum wage, and of these, $80 \%$ do not have social security (Mestries, 2013).

It is necessary to understand the concept of entrepreneurship (Table 2) in order to analyze it from an economic and social point of view, and then, later, to understand it as an area of opportunity in the educational and labor reintegration of returned migrants.

Table 2 Some definitions of entrepreneurship

\begin{tabular}{|c|c|}
\hline Author & Definition \\
\hline $\begin{array}{c}\text { Pontón y Márquez, } \\
\text { 2016, P.4 }\end{array}$ & $\begin{array}{l}\text { It is a social perception of success, is determined by } \\
\text { perseverance and the use of opportunities presented by the } \\
\text { society that surrounds the individual. It consists of relating the } \\
\text { entrepreneur with the concepts of innovation, development, } \\
\text { change, motivation, among others; It is a necessity for } \\
\text { Millennials, they see it related from the base of the } \\
\text { entrepreneur spirit, which is related to the attributes of the } \\
\text { person. }\end{array}$ \\
\hline $\begin{array}{l}\text { Serrano, Pérez, Palma, } \\
\text { López, 2016, P.13 }\end{array}$ & $\begin{array}{c}\text { From a qualitative point of view, it can be said that in } \\
\text { entrepreneurship a highly diversified field is observed, with a } \\
\text { wide variety of topics that are being analyzed, which indicates } \\
\text { an advance in the process of consolidating entrepreneurship as } \\
\text { a scientific discipline. }\end{array}$ \\
\hline $\begin{array}{l}\text { Druker y Steveson; } \\
\text { citado en Bucardo, }\end{array}$ & $\begin{array}{l}\text { It is the search for an opportunity, leaving aside the resources } \\
\text { that are available; it is not a purely intuitive behavior, of } \\
\text { character, it has a theoretical, conceptual basis; economic and } \\
\text { social basis, to do something different. It is the ability of }\end{array}$ \\
\hline
\end{tabular}




\begin{tabular}{|c|c|}
\hline $\begin{array}{c}\text { Saavedra y Camarena, } \\
2015, \text { P.3 }\end{array}$ & $\begin{array}{l}\text { entrepreneurs not only to take advantage of opportunities, but } \\
\text { also to face the challenges entailed by the lack of resources to } \\
\text { carry them out. }\end{array}$ \\
\hline García, 2015, P.9 & $\begin{array}{l}\text { Formal and legal process that is carried out by young subjects, } \\
\text { oriented to satisfy a specific need in the market, contributing } \\
\text { with this to strengthen the labor market, of goods, techniques } \\
\text { and / or services, by taking advantage of the structural } \\
\text { opportunities that exist. }\end{array}$ \\
\hline $\begin{array}{c}\text { García, Deniz, Cuellar, } \\
\text { 2015, P.25 }\end{array}$ & $\begin{array}{l}\text { Entrepreneurship can be analyzed from the angle of the } \\
\text { individual, and according to their attitude, intention and / or } \\
\text { entrepreneurial behavior, inside or outside the company, but } \\
\text { also referred to the performance of the whole company. }\end{array}$ \\
\hline $\begin{array}{c}\text { Messina y Hochsztain, } \\
\text { 2015,P.2 }\end{array}$ & $\begin{array}{l}\text { Entrepreneurship is considered to be an increasingly important } \\
\text { factor in contributing to economic development, the generation } \\
\text { of jobs, social inclusion, poverty reduction and the } \\
\text { development of innovation. }\end{array}$ \\
\hline $\begin{array}{c}\text { Nicolaou y Shane, } \\
\text { 2014,P.1 }\end{array}$ & $\begin{array}{c}\text { Entrepreneurship represents a social phenomenon that has tried } \\
\text { to be explained from the perspective of Biology or } \\
\text { Neuroscience, since Neuroscience would complement other } \\
\text { aspects of entrepreneurship. For example, neuroscience would } \\
\text { complement genetic research in entrepreneurship, among } \\
\text { others. }\end{array}$ \\
\hline $\begin{array}{l}\text { Newland y Tanaka, } \\
\text { 2010; citado en Tovar } \\
\text { y Victoria 2013, P.2 }\end{array}$ & $\begin{array}{l}\text { It contributes to the development of countries of origin, } \\
\text { stimulates innovation, encourages the creation of small and } \\
\text { medium-sized enterprises and generates employment, as well } \\
\text { as creating social capital across borders. }\end{array}$ \\
\hline $\begin{array}{l}\text { Rodríguez, } \\
\text { 2009,P.3-4 }\end{array}$ & $\begin{array}{l}\text { It is derived from the French term entrepreneur, which means } \\
\text { entrepreneur, the term has evolved and characterizes the person } \\
\text { in a state of permanent innovation, highly motivated and } \\
\text { committed to a task, which reports planning and execution } \\
\text { characteristics, prone to risk. It appears as a result of the ability } \\
\text { to persist in the game of being an entrepreneur. }\end{array}$ \\
\hline $\begin{array}{l}\text { Shumpeter,1978; } \\
\text { citado en Trujillo y } \\
\text { Guzmán, 2008, P.9 }\end{array}$ & $\begin{array}{l}\text { Entrepreneurship is related to the Individual capable of } \\
\text { breaking the economic equilibrium through innovation in a } \\
\text { radical way and to focus it towards a world dominated by large } \\
\text { corporations and where the entrepreneur is conditioned to } \\
\text { industrial change driven by incremental innovation; Innovation } \\
\text { is the raison of being entrepreneurship. }\end{array}$ \\
\hline
\end{tabular}

Source: own elaboration, various sources; 2017

There is evidence that shows that the practice of entrepreneurship is a strategy to face the difficulties of integration into the labor market of the country of return. The most optimistic views interpret that returnees are expected to be entrepreneurs and that independent work prevails, reflecting the success of a migratory experience in which human capital and savings were accumulated after years of residence abroad (Whaba and Zenou, 2012).

The entrepreneurial attitude, as a cornerstone of strategic flexibility, can be considered a key factor for the development of an entrepreneur: his 
skills, knowledge, skills, experience and values are triggering agents of the business attitude that is forged at the beginning and during the development; likewise, this attitude is an initiative behavior to promote the constant development of creative ideas and generate improvements in their environment (Rodríguez, Pico, Méndez, 2013).

\section{Entrepreneurship linked with educational and labor reintegration of returned migrants}

With respect to the return-entrepreneurship relationship (Table 3), the factors that are frequently linked to the particularities of the migratory stay are the accumulated savings, the duration and the acquired work experience (Alarcón and Ordoñez, 2015).

Table 3 Return studies of migrants linked to: educational reinsertion, labor reintegration and entrepreneurship

\begin{tabular}{|c|c|}
\hline Author & Variables and / or contributions \\
\hline $\begin{array}{c}\text { Alarcón et al. ,2012, citado en } \\
\text { Correa y Tituaña, } \\
2017\end{array}$ & $\begin{array}{l}\text { They explored the factors related to the decision to carry out } \\
\text { projects in Loja (Ecuador) from a survey of returnees, finding } \\
\text { that the variables that increase the probability of undertaking } \\
\text { after the return are the entrepreneurial experience during the } \\
\text { migration and the return for voluntary reasons, as well as having } \\
\text { worked abroad in agriculture and hospitality activities. }\end{array}$ \\
\hline Espinoza y González, 2016 & $\begin{array}{l}\text { They presented a qualitative study that aimed to establish the } \\
\text { regularities of the return process experienced by migrants, mainly } \\
\text { in social interaction in their place of origin, the effect of their } \\
\text { migration experience on the accumulation of social capital, and } \\
\text { how this change it affects their work activity and empowerment } \\
\text { in their social environment. A study was carried out, based on the } \\
\text { analysis of } 189 \text { interviews with returning migrants from the town } \\
\text { of Atencingo, Puebla, Mexico, who migrated to the United } \\
\text { States. In this study, } 22 \text { interviews considered the most } \\
\text { significant were used. }\end{array}$ \\
\hline Jáuregui y Recaño ,2014 & $\begin{array}{l}\text { Return migration can become a strategy to maximize income in } \\
\text { the country of origin and take advantage of the accumulated } \\
\text { human capital in the country of destination. Therefore, the } \\
\text { accumulation of human capital can affect the probability of } \\
\text { return. However, the acquired human capital - labor experience } \\
\text { and schooling - in the country of destination can become an } \\
\text { obstacle for the migrant to successfully insert himself into the } \\
\text { labor market of his country of origin upon return. }\end{array}$ \\
\hline Mendoza, 2013 & $\begin{array}{l}\text { Through a multivariate regression analysis, it shows that in } \\
\text { Mexico, return migration tends to put pressure on the formal } \\
\text { labor market by increasing regional differences in unemployment } \\
\text { rates; In addition, it determines that return migration has a } \\
\text { positive effect on the growth of GDP per capita, especially from } \\
\text { the impact of education levels of return migrants. }\end{array}$ \\
\hline Tovar y Paredes, 2013 & $\begin{array}{l}\text { The relationship between return migration and entrepreneurship } \\
\text { can contribute to the development of the countries of origin, } \\
\text { stimulate innovation, encourage the creation of small and } \\
\text { medium enterprises and generate employment, as well as create }\end{array}$ \\
\hline
\end{tabular}




\begin{tabular}{|c|c|}
\hline & $\begin{array}{l}\text { social capital across borders. Some emitting and receiving } \\
\text { countries of development, among them Colombia, Bolivia and } \\
\text { Peru, have adopted measures to promote return and facilitate the } \\
\text { incorporation of migrants in the local labor market, through } \\
\text { programs of employment or support for entrepreneurship; since } \\
\text { these countries face problems of capital restrictions. }\end{array}$ \\
\hline Medina y Posso, 2011 & $\begin{array}{l}\text { They studied the relationship of education, qualification for } \\
\text { employment and entrepreneurship as a basis for making the } \\
\text { decision to return to the place of origin of these Colombian and } \\
\text { South American immigrants in the United States. They suggest } \\
\text { that, during the migration period, returnees acquire experience } \\
\text { and general and specific skills that can contribute to the } \\
\text { development of the countries of origin if they are empowered and } \\
\text { take advantage of self-employment and entrepreneurship } \\
\text { activities. }\end{array}$ \\
\hline $\begin{array}{l}\text { Montoya, Salas y Soberón, } \\
2011\end{array}$ & $\begin{array}{l}\text { They emphasize the fact that the returnees: they have maintained } \\
\text { the same job they did abroad, they have acquired new skills that } \\
\text { allow them to integrate into different labor markets, and have } \\
\text { dedicated themselves to their own businesses; that is, migration } \\
\text { to the United States of America served as a means of } \\
\text { capitalization and business creation. }\end{array}$ \\
\hline Démurger y Xu, 2011 & $\begin{array}{l}\text { In their study Return Migrants in Anhui Province (China), } \\
\text { returnees are more likely to be entrepreneurs than non-migrants, } \\
\text { and both savings and job change in the country of destination } \\
\text { increase this probability. }\end{array}$ \\
\hline
\end{tabular}

Source: own elaboration, various sources; 2017

In order to analyze the phenomenon of return migration it is important not to lose sight of the individual factors of each returnee, adding the conditions of each country -origin and recipient-, their support networks and, mainly, how the motive for migration can reach give an account of the situations that will affect the return (Pérez et al., 2013 cited in Cataño 2015).

\section{Methodology}

For the present article, an exploratory research was carried out on returned migration, educational reintegration, labor reintegration and entrepreneurship; where the social and economic implications of returning migrants at the time of their arrival were made known; the information collected derives from the analysis of publications in different international journals.

To enter and analyze the information, a categorical matrix was elaborated in which data were assigned such as: name of the journal, author, year and central theme of the publication -What was done, how was it done and what were its results-, in total, 52 articles were analyzed, which are the ones that allow us to give an account of the state of the findings in the period 2012-2017 against migration, especially return.

In relation to the search conditions, it was found that of the total of the articles consulted, 58\% were related to North American countries and 34\% 
corresponding to South American countries (Table 4), this allows to affirm that migration of return and entrepreneurship is a key issue for study, especially for Latin American countries.

Table 4 Total items consulted and segmented by continent

\begin{tabular}{|c|c|c|}
\hline Country & Continent & $\begin{array}{c}\text { Contribution by } \\
\text { continent }\end{array}$ \\
\hline México(29) & \multirow[t]{2}{*}{ North America } & \multirow{2}{*}{0.58} \\
\hline Pennsylvania (1) & & \\
\hline Colombia $(8)$ & \multirow{6}{*}{ South America } & \multirow{6}{*}{0.34} \\
\hline Chile (3) & & \\
\hline Ecuador(2) & & \\
\hline Argentina (1) & & \\
\hline Uruguay (2) & & \\
\hline Perú (1) & & \\
\hline Spain (3) & Europe & 0.06 \\
\hline Egypt (1) & África & 0.02 \\
\hline China (1) & Asia & 0.02 \\
\hline Total Magazines 52 & & 0.1 \\
\hline
\end{tabular}

The review process ends with analysis of the information to eliminate possible errors in the database, that is, documents that did not match the search conditions specified above.

\section{Conclusion}

From the review of the referenced literature, it was identified that the processes of readaptation of the migrant in his country of origin directly influence the human and monetary capital acquired during the migratory experience. One of the main conditions that occurred in the migrants returning to their country of origin was the readjustment or clash of values, beliefs and perceptions acquired abroad, generating that when returning, the returned migrant lived a process of readaptation of said values. The next condition found was that the process of readaptation is easier for returned migrants as their acquired experiences and the use of their knowledge obtained in the destination country were useful and applied in their daily life in the country of origin

The publications about return migration have focused on quantifying the phenomenon, describing it and achieving a conceptualization about the types and ways of returning; nevertheless, it is necessary to begin to deepen in topics such as the migratory experience seen from the experiences and insertion of the migrant to educational and work contexts; the return policies as guarantors for the insertion in the country of origin and entrepreneurship as 
a means of insertion into the working life of those who have returned with a qualified experience.

Finally, the return of the migrant has implications in all areas of society. The realization of this article focused on the educational and labor context and how this, when taken advantage of and linked to entrepreneurship, can be considered, first, as an independence in the economic sustenance and secondly as engines of development in their areas of origin; However, this does not guarantee business success, for this it is necessary to have an adequate economic, social, political and institutional environment and that the returned migrant has constant support and training at all times, so that their enterprises can remain in business. Over time; The conditions for returning vary in each country in accordance with migratory policies and migrant quality; it is required then, more investigations are carried out that deepen in the subject.

\section{References:}

1. Alarcón Silverio y Ordóñez Jessica, (2015); Ecuador: Retorno migratorio y emprendimiento en Loja, revista Cepal 117, Diciembre 2015.

2. Anguiano Téllez María Eugenia, Cruz Piñeiro Rodolfo y Garbey Burey, Rosa María (2013); Migración internacional de retorno: trayectorias y reinserción laboral de emigrantes veracruzanos, papeles de población núm. 77, julio / septiembre, 2013 México.

3. Barrios Valenzuela Llarela Alejandra y Palou Julián Berta, (2014); Educación intercultural en Chile: la integración del alumnado extranjero en el sistema escolar, Dialnet ISSN 0123-1294. Vol. 17. No. 3 Septiembre-Diciembre 2014, pp. 405-426. Universidad de La Sabana | Facultad de Educación.

4. Bucardo Castro Alberto, Saavedra García María Luisa y Camarena Adame María Elena, (2015); EL SEVIER; Hacia una comprensión de los conceptos de emprendedores y empresarios, Recibido el 25 de febrero -Aceptado el 10 de abril 2015. México

5. Canales, Alejandro, (2012); "La Migración mexicana frente a la crisis económica actual. Crónica de un retorno moderado" en Revista Interdisciplinaria de movilidad humana, año XX, núm. 39, pp. 117134, jul.2012.

6. Cataño Pulgarín, S. V. y Morales Mesa, S. A. (2015). La migración de retorno. Una descripción desde algunas investigaciones latinoamericanas y españolas. Revista Colombiana de Ciencias Sociales, 6(1), 89-112.

7. Cobo, Salvador, (2008); “¿Cómo entender la movilidad ocupacional de los migrantes de retorno? Una propuesta de marco explicativo para 
el caso mexicano, en Estudios Demográficos y Urbanos, núm. 23, pp. 159-177.

8. Contreras Contreras Alma Estefania, (2016); Política Migratoria de México hacia sus connacionales en Estados Unidos, Dialnet-Revista CIMEXUS Vol. XI, No.1, 2016 Recibido el 18 de enero de 2016Aceptado el 14 de junio de 2016.

9. Correa Quezada Ronny y Tituaña Castillo María del Cisne, (2017); "Factores determinantes del retorno de los ecuatorianos en España”. Revista nuestrAmérica 5 (10): 113-38.

10. Delgado Wise Raúl, Mañán García Oscar, (2005); Migración MéxicoEstados Unidos e integración económica, revista Scielo Polít. cult. no.23 México.

11. Démurger Sylvie, Xu Hui, (2011); Return migrants: The rise of new entrepreneurs in rural China. World Development, Elsevier, 2011, 39 (10), pp. 1847-1861.

12. Durand, Jorge, (2013); "Nueva fase migratoria", en Papeles de Población, Redalyc, vol. 19, núm. 77, Nueva época, julio-septiembre 2013, México.

13. Espinosa Márquez Araceli, González Ramírez Misael, (2016); La adaptación social de los migrantes de retorno de la localidad de Atencingo, Puebla, México, Revista Scielo, ISSN 2007-7521. 11(1): 49-64 (Jul - Dic 2016); Recibido el 16 de Enero de 2015; Aprobado el 16 de Marzo de 2016.

14. Fabre Platas Danú A, (2016); migración retorno; Revista de Ciencias Sociales, IIESES, UV, México, Clivajes., (ISSN: 2395-9495), Año III, Núm. 5, enero-junio 2016.

15. Gandini Luciana, Lozano Ascencio Fernando, Gaspar Olvera Selene, (2015); El retorno en el nuevo escenario de migración, CONAPO, primera edición 2015 ISBN: 978-607-427-270-3. México.

16. García García, Víctor Daniel, (2015); Emprendimiento Empresarial Juvenil: Una evaluación con jóvenes estudiantes de universidad Redalyc; Revista Latinoamericana de Ciencias Sociales, Niñez y Juventud, vol. 13, núm. 2, julio- diciembre, 2015, pp. 1221-1236; Centro de Estudios Avanzados en Niñez y Juventud; Manizales, Colombia.

17. García Cabrera Antonia Mercedes, Déniz Déniz María de la Cruz, Cuéllar Molina Deybbi G. (2015); Inteligencia emocional y emprendimiento posibles líneas de trabajo, cuadernos administrativos, Bogota (Colombia), 28 (51), julio diciembre 2015

18. Giorguli Silvia, Gutiérrez Edith, (2011); Niños y adolescentes en el contexto de la migración internacional entre México y Estados Unidos, Coyuntura Demográfica (no. 1), pp. 21-25. 
19. Hamann Edmund. T., Zúñiga Victor, (2011). Schooling, national affinity (ies), and transnational students in Mexico. En S. Vandeyar (ed.). Hyphenated selves: Immigrant identities within education contexts. Amsterdam: Rozenburg Publishers, UNISA. revista Digital Commons@University of Nebraska - Lincoln.

20. Hamann Edmund. T., Zúñiga, Victor. y Sánchez García Juan (2010). Transnational students' perspectives on schooling in the United States and Mexico: The salience of school experience and country of birth. En M. O. Ensor \& E. M. Gozdziak (eds.). Children and migration: At the crossroads of resiliency and vulnerability. Nueva York: Palgrave Macmillan revista DigitalCommons@University of Nebraska Lincoln.

21. Jáuregui Díaz José Alfredo, Recaño Valverde Joaquín, (2014); Una aproximación a las definiciones, tipologías y marcos teóricos de la migración de retorno, revista Biblio 3w: bibliográfica de geografía y ciencias sociales, Universidad de Barcelona, ISSN: 1138-9796. Vol. XIX, nº 1084, 30 de julio 2014.

22. Jensen Bryant, (2017); La enseñanza equitativa para los niños retornados a México, Sinectica recibido: 23 de septiembre de 2016. Aceptado para su publicación: 3 de febrero de 2017.

23. Joiko Sara, Vásquez Alba, (2016); Acceso y elección escolar de familias migrantes en Chile: "No tuve problemas porque la escuela es abierta, porque acepta muchas nacionalidades", Calidad en la educación no.45 Santiago Chile.

24. Koolhaas Martín, (2016); Migración internacional de retorno en el Uruguay y reinserción laboral en tiempos de crisis económica internacional, 2011-2013, Notas de Población $\mathrm{N}^{\circ} 103$ julio-diciembre de 2016 págs. $123-147$

25. Masferrer León Claudia, Sánchez Peña Landy, Rodríguez Abreu Mauricio, (2017); condiciones laborales de los migrantes de retorno de Estados Unidos, apuntes para la equidad, Colegio de México, Mayo 2017, núm. 2. México.

26. Medina Carlos Alberto, Posso Christian Manuel, (2011); Inmigrantes colombianos en Estados Unidos: educación, calificación laboral y decisión de retornar, Ensayos sobre Política económica, vol. 29, núm. 65, junio. 2011.

27. Mendoza Cota Jorge Eduardo, (2013); Migración de retorno, niveles educativos y desarrollo socioeconómico regional de México, Revista Scielo en estudios sociales, julio- diciembre 2013.

28. Messina María, Hochsztain Esther, (2015); Factores de éxito de un emprendimiento: Un estudio exploratorio con base en Técnicas de 
Data Mining, Revista Tec Empresarial, Abril - Julio 2015, Vol. 9 Núm. $1 /$ p. 31-40. Uruguay.

29. Mestries, Francis, (2013); Los migrantes de retorno ante un futuro incierto, Scielo, Sociológica (Méx.) vol.28 no.78 México.

30. Montoya Ortiz Merari Stephanie, González Becerril Juan Gabino (2015); Evolución de la migración de retorno en México: migrantes procedentes de Estados Unidos en 1995 y de 1999 a 2014, Redalyc, Papeles Población vol.21 no.85 Toluca jul/Sep 2015.

31. Montoya Arce Jaciel, Salas Alfaro Renato, Soberón Mora José Antonio, (2011); La migración internacional de retorno en el estado de México: oportunidades y retos para el aprovechamiento socioproductivo de sus capacidades, Suma de Negocios, Vol. $2 \mathrm{~N}^{\circ} 2$ : 45-62, diciembre 2011, Bogotá (Colombia).

32. Nicolaou Nicos, Shane Scott, (2014); Biology, Neuroscience, and Entrepreneurship, Journal of Management, Inquiry 2014, Vol 23(1) 98-100. Pennsylvania State.

33. Ocampo Marín Luis Fernando, (2014); Migración de retorno, familias transnacionales y demandas educativas, Revista Sociedad y Equidad $\mathrm{N}^{\mathrm{o}}$ 6, Enero 2014, México.

34. Osuna Nevado Carmen, (2012); en torno a la educación intercultural. Una revisión crítica, Revista de Educación, 358. Mayo-agosto 2012, pp. 38-58, Madrid, España.

35. Peña Muñoz, Jesús Javier, (2015); Perfil laboral de migrantes mexicanos deportados e inserción laboral en México; Migración y desarrollo_no.24 Zacatecas.

36. Pontón Deluquez, Elimar, Márquez López Carlos Mario,(2016);El Marketing como base para el emprendimiento de los Millenials, Palermo Business Review, Fundación Universidad de Palermo, Argentina, Graduate School of Business N ${ }^{\circ} 13$

37. Ramírez Telésforo y Daniel Aguado, (2013); "Determinantes de la migración de retorno en México, 2007-2009", en La Situación Demográfica de México, Consejo Nacional de Población (CONAPO), México.

38. Rivera Sánchez Liliana, (2013); migración de retorno y experiencias de reinserción en la zona metropolitana de la ciudad de México; Revista. Interdisciplinaria movilidad humana, Año XXI, n. 41, p. 5576, julio 2013.

39. Rivera Sánchez Liliana, (2015); Sujetos móviles y pertenencias urbanas. Notas en torno a una investigación sobre prácticas y experiencias de reinserción social de migrantes retornados a espacios urbanos, México, Estudios Sociológicos XXXIII: 97. 
40. Rodríguez Ramírez Alfonso' (2009); Nuevas perspectivas para entender el emprendimiento empresarial, Revista Scielo Pensamiento y gestión no.26 Barranquilla, Colombia Jan./June 2009.

41. Rodríguez Suárez Pedro Manuel, Pico González Beatriz, Méndez Ramírez Francisco Javier, (2013); Capacidad innovadora en la empresa familiar como área de oportunidad hacia el desarrollo de México, Economía, Sociedad y Territorio, vol. XIII, núm. 43, 2013, 779-794.

42. Salas Natalia, Kong Felipe, Gazmuri Renato; (2017); La Investigación socio territorial: Una Propuesta para Comprender los Procesos de Inclusión de los Migrantes en las Escuelas; Revista Latinoamericana de Educación Inclusiva, 11(1), 73-91, Chile.

43. Sánchez Bautista Consuelo, (2014); La migración intrarregional de niños andinos y su derecho a la educación en los países receptores, Andina migrante, Boletín del Sistema de Información sobre Migraciones Andinas - FLACSO Sede Ecuador,N. ${ }^{\circ} 17$.

44. Serrano Bedia Ana María; Pérez Pérez Marta; Palma Ruiz Manuel; López Fernández María Concepción, (2016); Emprendimiento: visión actual como disciplina de investigación. Un análisis de los números especiales publicados durante 2011-2013, Estudios Gerenciales, vol. 32, núm. 138, enero-marzo, 2016, pp. 82-95, Universidad ICESI Cali, Colombia.

45. Tijoux Merino María Emilia, (2013); Niños(as) marcados por la inmigración Peruana: estigma, sufrimientos, resistencias; convergencia vol.20 no.61. ene./abr 2013.

46. Tovar Cuevas Luis Miguel, Victoria Paredes María Teresa, (2013); Migración internacional de retorno y emprendimiento: revisión de la literatura, revista Scielo de economía institucional, vol. 15, n. ${ }^{\circ} 29$, segundo semestre, pp. 41-65, Cali, Colombia.

47. Trujillo Dávila María Andrea, Guzmán Vásquez Alexander, (2008) Intraemprendimiento: una revisión al constructo teórico, sus implicaciones y agenda de investigación futura Cuadernos de Administración, vol. 21, núm. 35, enero-junio 2008, pp. 37-63 Pontificia Universidad Javeriana Bogóta, Colombia.

48. Vargas Valle Eunice D, (2015); Cambiarse de escuela Inasistencia y rezago escolar de los niños de migración reciente de Estados Unidos a México, Norteamerica, Volumen 10, Issue 2, July-December 2015, Pages 157-186.

49. Wahba Jackline a, Zenou Yves, (2012); Out of sight, out of mind: Migration, entrepreneurship and social capita, EL SEVIER Regional Science and Urban Economics 42 (2012) 890-903.Egipto. 
50. Zúñiga Víctor, (2013); Migrantes internacionales en las escuelas mexicanas: desafíos actuales y futuros de política educativa, Revista Sinéctica (no. 40), pp. 1-12; enero-junio 2013.

51. Zúñiga, V., Hamann, E. T. y Sánchez García, J. (2008). Alumnos transfronterizos: las escuelas mexicanas frente a la globalización. México, DF. Revista DigitalCommons@University of Nebraska Lincoln.

52. Zúñiga, V., Hamann, E. T. (2009). Sojourners in Mexico with US school experience: A new taxonomy for transnational students. Comparative Education Review, 53 (3), 329-353. Mayo 2009. Recuperado, revista DigitalCommons@University of Nebraska - Lincoln. 